\title{
STRATEGI PEMASARAN SYARIAH DALAM MENINGKATKAN DAYA SAING UMKM KERUPUK DESA TLASIH TULANGAN SIDOARJO
}

\author{
Mahilda Anastasia Putri ${ }^{1} \&$ Renny Oktafia ${ }^{2}$ \\ ${ }^{1}$ \&2 Fakultas Agama Islam, Universitas Muhammadiyah Sidoarjo \\ Email: anastasiamahilda@gmail.com,renny.oktafia@umsida.ac.id
}

\begin{abstract}
ABSTRAK
Strategi pemasaran dapat dipandang sebagai salah satu dasar yang dipakai dalam menyusun perencanaan sebuah perusahaan atau pabrik secara menyeluruh. Dalam kegiatan pemasaran sering kali menjumpai orang yang curang dan terjadi penipuan, tetapi jika kita menerapkan sistem Islam dalam pemasaran maka hal-hal seperti itu tidak akan terjadi. Pada dasarnya, bagi umat Islam Nabi Muhammad SAW telah mengajarkan kita bagaimana sistem pemasaran Islami. Namun, karena masyarakat telah bertumpu pada sistem pemasaran konvensional, maka sistem pemasaran syariah kurang dikenal. Penelitian ini memiliki tujuan untuk mendapat gambaran mengenai strategi pemasaran untuk meningkatkan daya saing, dan untuk mengetahui seberapa efektif pelaksanaan strategi pemasaran yang telah dilakukan. Jenis penelitian ini yaitu kualitatif, penelitian ini dilakukan di UMKM Kerupuk Desa Tlasih. Teknik pengumpulan datanya dengan dokumentasi dan wawancara. Hasil dari analisis efektifitas strategi pemasaran menunjukkan adanya peningkatan penjualan dari bulan ke bulan dan pernah mengalami penurunan penjualan hal ini dapat dijadikan sebagai acuan efektifitas strategi pemasaran dalam persaingan antar pabrik kerupuk.
\end{abstract}

Kata Kunci: Strategi Pemasaran Syariah, Daya Saing, UMKM, Analisis SWOT.

\begin{abstract}
Marketing strategy can be seen as one of the basics used in planning a company or factory as a whole. In marketing activities, we often encounter people who cheat and fraud occurs, but if we apply the Islamic system in marketing then things like that will not happen. Basically, for Muslims the Prophet Muhammad SAW has taught us how to use an Islamic marketing system. However, because society has relied on the conventional marketing system, the sharia marketing system is less well known. This study aims to get an overview of the marketing strategy to increase competitiveness, and to find out how effective the implementation of the marketing strategy has been. This type of research is qualitative, this research was carried out in the Kerupuk UMKM, Tlasih Village. Data collection techniques with documentation and interviews. The results of the analysis of the effectiveness of marketing strategies show an increase in sales from month to month and have experienced a decline in sales, this can be used as a reference for the effectiveness of marketing strategies in competition between cracker factories.
\end{abstract}

Keywords: Sharia Marketing Strategy, Competitiveness, MSMEs, SWOT Analysis. 


\section{PENDAHULUAN}

Peranan Usaha Mikro Kecil Dan Menengah (UMKM) yang sangat besar dapat memberikan penjabaran bahwa Usaha Mikro Kecil dan Menengah (UMKM) dapat ditingkatkan lebih baik lagi dalam sektor pemasarannya. Usaha Mikro Kecil Dan Menengah (UMKM) akan mampu bertahan apabila menerapkan pengelolaan manajemen dengan baik. Pengelolaan manajemen tersebut seperti di bidang pemasaran, produksi dan sumber daya manusia yang baik. Perancangan sebuah strategi pemasaran sangat diperlukan guna lebih meningkatkan nilai jual suatu Usaha Mikro Kecil Dan Menengah (UMKM), serta dinilai memiliki peluang yang mampu mensejahterakan masyarakat secara meluas.

\section{Sebagaimana Kegiatan PPM-} UMKM Geo UMKM telah berhasil membuat sebuah website yang memuat database online data UMKM Desa Kenongo, dengan adanya perkembangan infrastruktur di Desa Kenongo dan banyaknya pendatang karena adanya bencana lumpur Lapindo ini membuka peluang para warga desa Kenongo untuk membuka usaha atau UMKM baik itu di bidang jual beli makanan, bahan pokok dan kebutuhan sehari-hari lagi (Latifah et al, 2019).

Dalam kegiatan bisnis, istilah pemasaran sering kali dikaitkan oleh banyak pihak dengan penjualan adapun berbagai macam kegiatan seperti sales, iklan, dan promosi. Bahkan seringkali orang menyamakan profesi marketer (pemasar) dengan sales (penjual). Namun sebenarnya pemasaran tidaklah sesempit yang diketahui oleh banyak orang, karena pemasaran berbeda dengan penjualan.

Untuk mencapai sasaran pemasaran para pelaku usaha dagang sebagian besar memerlukan sumber modal untuk berjalannya suatu usaha, bagi mereka sumber modal sangatlah penting karena dengan modal usaha para pengusaha bisa tetap menjaga keberlangsungan usahanya dan dapat terpenuhi kebutuhan lainnya
(Ningsih \& Maika, 2020).

Menurut prinsip syariah, kegiatan pemasaran harus dilandasi semangat dalam beribadah kepada Tuhan Sang Maha Kuasa, berusaha semaksimal mungkin untuk kesejahteraan bersama, bukan untuk kepentingan golongan apalagi untuk kepentingan sendiri. Pemasaran syariah merupakan sebuah strategi yang dimana proses baik proses penciptaan, proses penawaran, maupun proses perubahan nilai, tidak diperbolehkan adanya hal yang bertentangan dengan akad dan prinsip-prinsip muamalah yang Islami. Sepanjang hal tersebut dapat dijamin, dan penyimpangan prinsip-prinsip muamalah Islami tidak terjadi dalam suatu transaksi dalam pemasaran dapat dibolehkan.

Di dalam sebuah unit perusahaan kebanyakan hanya melakukan kegiatan yang berfokus pada pembuatan produk saja. Seharusnya strategi pemasaran yang ada di dalam sebuah perusahaan harus dipertahankan agar usaha yang ada dapat tetap bersaing dengan usaha yang lain. Strategi pemasaran salah satunya untuk memenangkan keunggulan dalam bersaing baik untuk perusahaan yang memproduksi barang atau jasa. Strategi pemasaran dibutuhkan pendekatan-pendekatan analisis dengan mengetahui kekuatan dan kelemahan serta peluang dan ancaman dalam sebuah pabrik atau perusahaan, agar mampu dalam menghadapi perubahan lingkungan internal maupun eksternal.

Sebagaimana pertumbuhan Usaha Mikro, Kecil dan Menengah (UMKM) dapat semakin cepat pergerakannya, melalui peran dan dukungan dari Lembaga Keuangan Mikro Syariah (LKMS). Dengan program pemberdayaan ekonomi yang dijalankan LKMS, dapat semakin memperkuat UMKM dalam memperluas skala usahanya. Untuk bisa semakin meningkatkan perannya, dalam memberikan pelayanan pembiayaan yang maksimal kepada UMKM (Oktafia 2017).

Analisis kekuatan (strenghts), kelemahan (weakness), peluang (opportunies) 
dan ancaman (threats) merupakan sarana untuk melihat seberapa mampu sebuah pabrik atau perusahaan dalam menghadapi masalah tersebut, untuk mengetahui kelemahan, kekuatan, peluang dan ancaman perlu menggunakan analisis SWOT. Analisis ini dapat mengidentifikasi faktor eksternal dan internal, supaya bisa mengetahui sejauh mana perusahaan dapat meningkatkan penjualannya dengan mengetahui dan memanfaatkan setiap peluang yang ada dengan berbagai kondisi sehingga dapat mencegah ancaman yang akan dihadapi dan mempertahankan kekuatan yang dimiliki dengan terus berinovasi sehingga kelemahan yang dimiliki perusahaan dapat perbaiki bahkan dihindari semaksimal mungkin.

Negara Indonesia saat ini mengalami pandemi Covid-19 yang membuat Usaha Mikro Kecil Dan Menengah (UMKM) mengalami kesulitan dalam kegiatan pemasaran, seperti halnya dengan permasalahan yang terjadi di Usaha Mikro Kecil Dan Menengah (UMKM) kerupuk Desa Tlasih Tulangan Sidoarjo saat ini yaitu, menurunnya daya jual pada usaha kerupuk, dan terdapat pula daya saing yang semakin ketat antara pengusaha lainnya. Dimana dalam lingkungannya sebagian besar memiliki usaha kerupuk, tentunya setiap rumah industri memiliki cara strategi pemasaran yang berbeda-beda.

Berikut ini data jumlah Usaha Mikro Kecil Dan Menengah yang ada di Jawa Timur Tahun 2019:

\section{Gambar1. Jumlah Data Usaha Mikro, Kecil, Menengah (UMKM)}

\section{di Jawa Timur Tahun 2019}

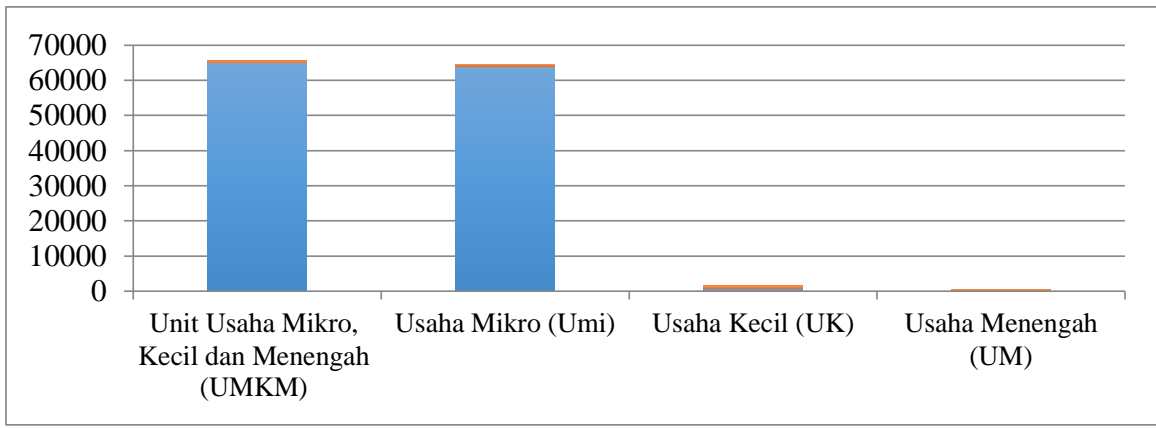

Sumber : Kementrian Koperasi dan UKM Republik Indonesia (2019)

Desa Tlasih merupakan sebuah Desa yang terletak di Kecamatan Tulangan Kabupaten Sidoarjo yang memiliki total luas wilayah $118.3917 \mathrm{~km}^{2}$ dan penduduk sebanyak 3656 jiwa. Sebagian besar matapencaharian di desa ini menjadi petani namun tidak seluruhnya masyarkat Desa Tlasih menjadi petani tetapi ada juga yang memilih untuk berwirausaha dengan mendirikan rumah industri (home industry). Tidak mudah untuk mengenalkan produk home insdutry dari Desa Tlasih meskipun di kalangan desa tersebut memiliki beberapa home industry yang sebagian besar memproduksi kerupuk. Maka dari itu betapa pentingnya sebuah strategi pemasaran untuk memasarkan produk di kalangan home industry kerupuk.
Berdasarkan pada latar belakang dan permasalahan yang terjadi di atas, maka dilaksanakan penelitian yang berjudul strategi pemasaran syariah dalam Meningkatkan daya saing Usaha Mikro Kecil Dan Menengah (UMKM) kerupuk Desa Tlasih Tulangan Sidoarjo.

\section{TINJAUAN PUSTAKA}

\section{Pengertian Strategi Pemasaran}

Strategi pemasaran adalah kegiatan melalui perencanaan, penentuan harga, mempromosikan dan mendistribusikan barang dan jasa yang memuaskan dan memenuhi kebutuhan pembeli. Strategi pemasaran dapat dipahami dengan berbagai cara untuk meyakinkan dan mendapatkan 
kepercayaan pelanggan pasar. Adapun strategi tersebut berupa kualitas produk yang ditawarkan, promosi yang memikat, rasayang tetap terjaga, lokasi yang strategis, dan harga yang bersaing (Ariwibowo, 2019).

Menurut Chandra (2009) dalam Atmoko (2018) strategi pemasaran merupakan rencana yang menjabarkan ekspektasi perusahaan akan dampak dari berbagai aktivitas atau program pemasaran terhadap permintaan produk atau lini produknya di pasar sasaran tertentu. Program pemasaran meliputi tindakan-tindakan pemasaran yang dapat mempengaruhi permintaan terhadap produk, diantaranya dalam hal mengubah harga, memodifikasi kampanye iklan, merancang promosi khusus, menentukan pilihan saluran distribusi, dan sebagainya.

\section{Daya Saing}

Daya saing atau dikenal dengan kata persaingan merupakan sebuah inti dari keberhasilan atau kegagalan suatu perusahaan. Persaingan dapat menentukan ketepatan aktifitas perusahaan yang dapat mendukung kinerjanya, daya saing sendiri yaitu sebuah konsep perbandingan kinerja perusahaan dan kemampuan, sub-sektor atau negara untuk menjual dan memasok barang atau jasa yang diberikan dalam pasar.

Menurut Crown Dirgantoro dalam Mohamad dan Niode (2020), daya saing yaitu suatu perkembangan dari nilai yang mampu diciptakan untuk membelinya. Adapun faktor yang mempengaruhi daya saing antara lain:

1. Faktor persaingan dan strategi bisnis.

2. Industri pendukung dan produk subtitusi.

3. Kondisi permintaan lokal serta peran pemerintah dan peluang.

4. Faktor ini dapat menggambarkan kondisi daya saing sebuah Negara atau industri.

\section{Usaha Mikro Kecil Dan Menengah}

Usaha Mikro Kecil dan Menengah (UMKM) merupakan suatu bisnis atau usaha yang dijalankan oleh perseorangan, rumah tangga, dan badan usaha kecil. Permasalahan ekonomi seperti kemiskinan ini dapat ditanggulangi dengan meningkatkan sektor Usaha Mikro Kecil dan Menengah (UMKM) dan meningkatkan pertumbuhan ekonomi agar tidak bertambah angka kemiskinan di suatu negara.

Selama ini Usaha Mikro Kecil dan Menengah (UMKM) masih memiliki banyak keterbatasan dan kendala, salah satunya kedala perekonomian masyarakat. Modal utama pembangunan perekonomian Indonesia bergantung pada keberadaan Usaha Mikro Kecil dan Menengah (UMKM) yang handal dan kuat dalam memasarkan produknya (Sani et al, 2019).

Semakin banyak masyarakat yang berwirausaha maka semakin baik dan kokohnya perekonomian disuatu daerah atau Negara karena sumber daya lokal, pekerja lokal, dan pembiayaan lokal dapat terserap dan bermanfaat secara optimal. Oleh karena itu, Usaha Mikro Kecil dan Menengah (UMKM) merupakan sebuah potensi yang sangat berpengaruh pada perekonomian di Indonesia.

Kinerja Usaha Mikro Kecil dan Menengah (UMKM) merupakan hasil evaluasi kerja perusahaan uang digapai oleh seseorang atau kelompok dengan pembagian kegiatan berupa tugas dan perannya. Kinerja Usaha Mikro Kecil dan Menengah (UMKM) dapat dilihat melalui beberapa indikator diantaranya melalui, pencatatan keuangan, modal usaha, tenaga kerja yang diserap lalu di jalankan sesuai apa yang di dapat (Sudiarta \& Kirya, 2014).

Lemahnya kemampuan manajerial dan sumber daya manusia ini mengakibatkan pengusaha kecil tidak mampu menjalankan usahanya dengan baik, dan menghadapi masalah-masalah yang akan datang di kemudian hari apabila kemampuan manajerial dan sumber daya manusianya 
tidak di perbaiki. Adapun beberapa masalah yang akan dihadapi oleh Usaha Mikro Kecil dan Menengah (UMKM) yaitu :

1. Kelemahan dalam memperoleh peluang pasar.

2. Kelemahan di bidang organisasi dan menajemen sumber daya manusia.

3. Keterbasan jaringan usaha kerja sama antar pengusaha kecil.

4. Iklim usaha yang kurang kondusif karena persaingan yang sangat ketat.

\section{Pemasaran Syariah}

Pemasaran menurut perspektif syariah yaitu kegiatan berbisnis yang memungkinkan siapapun melakukannya bertumbuh serta mempergunakan kemanfaatannya yang dilandasi sikap kejujuran, keadilan, keterbukaan dan keikhlasan sesuai dengan prinsip pada akad bermuamalah islami atau perjanjian transaksi bisnis dalam Islam. Adapun tujuan dari penerapan syariah di dalam sebuah pemasaran yaitu untuk kemaslahatan umat manusia, karena Allah SWT telah menurunkan perintah maupun larangan agar terjaga keseimbangan dalam kehidupan dan manusia memperoleh kemaslahatan bagi dirinya.

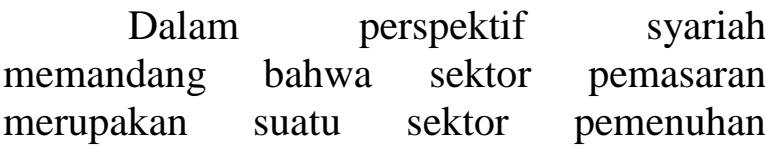
kebutuhan hidup yang dibolehkan, asalkan dilakukan dengan cara yang benar yang jauh dari unsur kebatilan. Sebagaimana yang di jelaskan dalam surah An-Nisa (4) ayat 29 yang berbunyi:

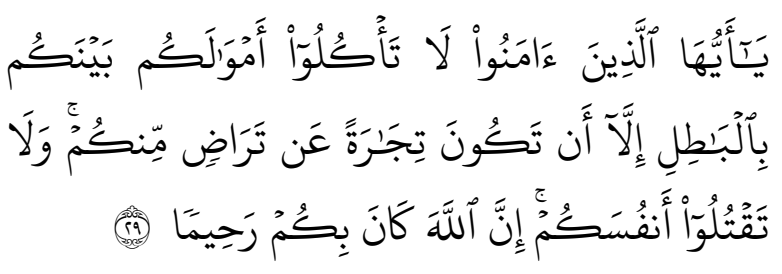

Artinya : "Wahai orang-orang yang beriman! janganlah kamu saling memakan harta sesamamu dengan jalan yang batil (tidak benar), kecuali dalam perdagangan yang berlaku atas dasar suka sama suka di antara kamu. Dan janganlah kamu membunuh dirimu. Sungguh, Allah maha penyayang kepadamu." (Q.S. An Nisa ayat 29)

Dari terjemahan ayat di atas, menunjukkan bahwa segala kegiatan ekonomi, dapat dijalankan dengan upaya pemasaran perdagangan atau yang benar dan yang jauh dari unsur kebatilan (Nurcholifah, 2014).

\section{Analisis SWOT}

Analisis SWOT merupakan sebuah identifikasi faktor eksternal dan internal. Analisis ini digunakan untuk mengetahui sejauh mana perusahaan dapat meningkatkan penjualannya dengan mengetahui dan memanfaatkan setiap peluang yang ada dengan berbagai kondisi sehingga dapat mencegah ancaman yang akan dihadapi dan mempertahankan kekuatan yang dimiliki dengan terus berinovasi sehingga kelemahan yang dimiliki perusahaan dapat perbaiki bahkan dihindari semaksimal mungkin

\begin{tabular}{lcr}
\multicolumn{1}{c}{ Analisis } & $\begin{array}{c}\text { kekuatan } \\
\text { (weakness), }\end{array}$ & (strenghts), \\
kelemahan & peluang \\
(opportunies) & dan ancaman & (threats)
\end{tabular} merupakan sarana untuk melihat seberapa mampu sebuah pabrik atau perusahaan dalam menghadapi masalah tersebut, untuk mengetahui kelemahan, kekuatan, peluang dan ancaman perlu menggunakan analisis SWOT. (Sukatmadiredja \& Rosita, 2019).

\section{METODE PENELITIAN}

\section{Jenis Penelitian}

Penelitian ini penelitian ini menggunakan metode kualitatif yang membahas tentang strategi pemasaran yang diterapkan di Desa Tlasih dalam sektor Usaha Mikro Kecil dan Menengah (UMKM). Peneliti melakukan penelitian secara langsung di Desa Tlasih untuk dapat mengetahui strategi pemasaran pada sektor Usaha Mikro Kecil dan Menengah (UMKM) serta dampak dalam meningkatkan daya saing Usaha Mikro Kecil dan Menengah (UMKM).

Kemudian jenis pendekatan yang digunakan oleh peneliti yaitu studi kasus 
karena penelitian dilakukan terhadap informan yang bersangkutan seperti pemilik usaha Usaha Mikro Kecil dan Menengah (UMKM) Kerupuk.

\section{Sumber Data}

Penelitian ini menggunakan dua jenis data yaitu data primer dan data sekunder. Peneliti menggunakan data primer yang diambil melalui wawancara kepada pemilik UMKM Kerupuk Desa Tlasih. Sedangkan data sekunder yang diperoleh dari referensi pustaka yang menjadi acuan dalam penelitian yang didapatkan dari website resmi Kementrian Koperasi Dan UMKM Republik Indonesia dan karya ilmiah dari penelitian terdahulu (Kusumastuti \& Khoiron, 2019).

\section{Teknik Pengumpulan Data}

Teknik pengumpulan data yang digunakan untuk penelitian ini terdiri dari tiga macam yaitu observasi, wawancara dan dokumentasi (Raco, 2018).

1. Observasi, peneliti mengamati terkait aktivitas yang dilakukan oleh pihak informan pada tempat penelitian. Objek yang diamati oleh peneliti adalah place, actor, activity. Peneliti memiliki teknik observasi partisipasi pasif karena dalam penelitian hanya melihat kegiatan seharihari pada objek yang diamati tanpa ikut terlibat dalam kegiatan tersebut oleh karena itu peneliti hanya bertindak sebagai pengamat atau observer.

2. Wawancara, dalam melaksanakan wawancara peneliti menggunakan teknik wawancara terstuktur yang dimana teknik pengumpulan data dengan memberikan pertanyaan ke informan, informan yang dipilih oleh peneliti yaitu informan yang dipilih yaitu pemilik usaha Usaha Mikro Kecil dan Menengah (UMKM). Wawancara dilakukan oleh peneliti dengan mendatangi pemilik usaha Usaha Mikro Kecil dan Menengah (UMKM) kerupuk Desa Tlasih di siang hari.

3. Dokumentasi, merupakan salah satu pelengkap dari penggunaan metode pada observasi dan wawancara berupa foto sebagai bukti peneliti melakukan wawancara dengan informan, transkip rekaman suara peniliti dengan informan saat melakukan wawancara untuk mendapatkan data yang dibutuhkan peneliti dalam manjemen pengelolaan wakaf tanah dan jurnal penelitian terdahulu yang mendukung penelitian ini.

\section{Teknik Analisis dan Inteprestasi Data}

Teknik analisis dan interprestasi data yang dipilih yaitu model Miles dan Huberman dengan analisis reduksi data, penyajian data dan penarikan kesimpulan (Shidiq \& Choiri, 2019).

1. Reduksi data, digunakan ketika data yang didapat terlalu banyak sehingga harus memilah hal-hal penting yang dilakukan dengan cara merangkum data atau reduksi data. Reduksi data dalam penelitian ini dengan mengambil tema strategi pemasaran dalam Usaha Mikro Kecil dan Menengah (UMKM) untuk mempermudah peneliti mengambil kesimpulan.

2. Penyajian data, bersifat naratif yang berasal dari hasil wawancara peneliti kepada pemilik usaha kerupuk Desa Tlasih, data yang dijelaskan oleh informan data yang bisa digunakan untuk menjawab pertanyaan dari dua rumusan masalah.

3. Penarikan kesimpulan, merupakan penarikan inti dari keseluruhan data yang telah terkumpul dari penelitian. Dengan demikian, hasil dari penelitian memperoleh kesimpulan atau validasi dari penelitian terkait strategi pemasaran dalam meningkatkan daya saing UMKM Kerupuk yang dilakukan di Desa Tlasih.

\section{Uji Kredibilitas}

Tahap yang digunakan untuk memberikan keyakinan dari hasil penelitian yang bertujuan untu memperoleh data valid disebut uji kredibilitas. Teknik dalam menguji kredibilitas pada suatu data yang terdiri dari sumber, teknik dan waktu disebut dengantriangulasi (Nugrahani, 2014).

1. Triangulasi sumber 
Sumber data terkait strategi pemasaran didapatkan dari sumber yang berbeda yaitu yaitu pemilik usaha Usaha Mikro Kecil dan Menengah (UMKM) kerupuk Desa Tlasih. Dalam hal ini sumber data yang diberikan menghasilkan pernyataan yang sama jika dalam sektor Usaha Mikro Kecil dan Menengah (UMKM) dilakukan dengan menggunakan strategi pemasaran.

2. Triangulasi teknik

Untuk dapat menguji kreadibilitas data yang didapatkan dari informan yaitu pemilik usaha kerupuk Desa Tlasih dengan menggunakan teknik wawancara terkait strategi pemasaran pada sektor Usaha Mikro Kecil dan Menengah (UMKM) dan diuji kembali saat melakukan observasi di Desa Tlasih untuk bisa mendapatkan data yang sama saat wawancara dan dibuktikan saat melakukan observasi.

3. Triangulasi waktu
Dalam triangulasi waktu data terkait strategi pemasaran pada sektor Usaha Mikro Kecil dan Menengah (UMKM) didapatkan saat narasumber memiliki waktu luang untuk pemilik usaha Usaha Mikro Kecil dan Menengah (UMKM) Kerupuk Desa Tlasih yang dilakukan di siang hari agar tidak menganggu pihak yang lain.

\section{HASIL DAN PEMBAHASAN}

\section{Keadaan Ekonomi dan Sosial Warga Desa Tlasih}

Berdasarkan hasil pemetaan pada data pemetaan kelurahan Desa Tlasih 2021 Desa Tlasih memperoleh data sebanyak 3656 jiwa yang bermukim di Desa Tlasih dan memiliki sumber daya manusia yang cukup tidak terlalu padat penduduk juga tidak terlalu sedikit. Berdasarkan dari penelitian yang dilakukan oleh peneliti memperoleh data kondisi ekonomi desa sebagai berikut:

\section{Gambar 2. Kondisi Ekonomi Warga Desa Tlasih}

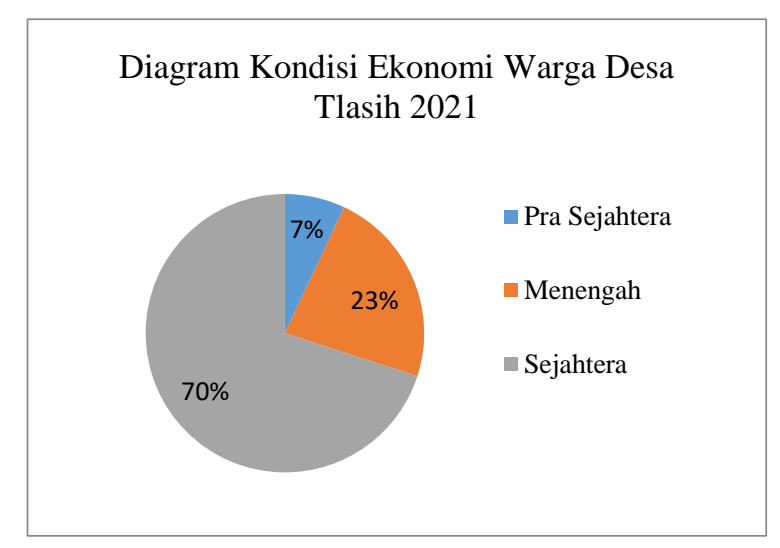

Sumber: Pemerintah Desa Tslasih (2021)

Dari gambar di atas dapat disimpulkan bahwa penduduk sejahtera sebesar 70\% dari jumlah penduduk 3656 jiwa. Desa Tlasih termasuk desa yang memadai dan sejahtera. Desa Tlasih merupakan sebuah desa yang terletak di Tulangan Sidoarjo, perekonomian masyarakat desa Tlasih sebagian besar berprofesi sebagai petani, tetapi penduduk Desa Tlasih tidak semua berprofesi sebagai petani adapun yang memiliki pabrik kerupuk tetapi ada juga berprofesi yang lain, ada yang menempuh pendidikan sampai SMA saja tetapi tidak menutup kemungkinan bisa membangun sebuah pabrik yang terletak di Desa Tlasih dan berharap produk lebih banyak dikenal oleh masyarakat luar daerah hingga mancanegara. 


\section{Penerapan Strategi Pemasaran Dalam Meningkatkan Daya Saing UMKM Krupuk Desa Tlasih Tulangan Sidoarjo}

Strategi pemasaran yang dilakukan oleh Usaha Mikro Kecil dan Menengah (UMKM) kerupuk Desa Tlasih dalam kegiatan pemasaran produknya dengan cara perumusan strategi pemasaran yang bermula dari segmentasi pasar (segmentation), strategi penentuan pasar sasaran (targeting), dan strategi posisi pasar (positioning). Selain itu juga dengan mengembangkan bauran pemasaran (marketing mix) yang terdiri dari 4 unsur yaitu produk, harga, tempat dan promosi.

\section{Strategi Segmentasi Pasar}

Langkah pertama yang dilakukan oleh pemilik Usaha Mikro Kecil dan Menengah (UMKM) kerupuk Desa Tlasih adalah mensegmentasi pasar. Adapun kriteria yang dibutuhkan dalam segmentasi pasar antara lain:

a. Segmentasi geografis adalah Bali.

b. Segmentasi demografis adalah konsumen yang tergolong cukup tua (40 tahun).

c. Segmentasi psikologis adalah semua masyarakat tak terbatas.

2. Strategi penentuan pasar sasaran (Targeting)

Demi meningkatkan pendapatan pabrik, pasti dilakukan pula penyesuaian pada pasar sasaran, agar penjualan menjadi tepat sasaran. Dalam hal ini untuk target pasar, Usaha Mikro Kecil dan Menengah (UMKM) kerupuk desa Tlasih telah menentukan targetnya. Memberikan harga jual Rp. 50.000- 60.000 (harga disesuaikan) dengan jumlah pembelian.

\section{Strategi Posisi Pasar (Positioning)}

Tidak ada strategi khusus, tetapi menambah variasi atau berbagai macam jenis kerupuk, menyediakan stok lebih banyak agar meningkatkan pembelian pembeli. Produk kerupuk merupakan solusi yang tepat untuk dikonsumsi semua jenis usia muda maupun tua, karena didalam produk kerupuk ini tidak menggunakan bahan pengawet dan tidak berbahaya bila dikonsumsi oleh segala jenis usia. Pemasaran yang diterapkan yaitu strategi pemasaran secara manual atau langsung, karena bisa mempromosikan atau memperkenalkan produk yang mereka miliki kepada distributor.

4. Bauran Pemasaran Usaha Mikro Kecil dan Menengah (UMKM) kerupuk Desa Tlasih (Marketing Mix)

Keberhasilan sebuah pabrik dibidang pemasaran terkait dengan hasilnya dalam menentukan produk yang tepat, harga yang layak, promosi yang efektif dan kegiatan dustribusi yang baik. Bauran pemasaran yang terdiri dari produk, harga, tempat dan promosi di tetapkan dengan amat baik oleh Usaha Mikro Kecil dan Menengah (UMKM) kerupuk Desa Tlasih agar kepuasan konsumen serta keberlanjutan usaha dapat terwujud.

a. Produk

Jika dilihat dalam perspektif syariah, suatu produk yang akan dipasarkan haruslah produk yang halal dan memiliki atau kualitas yang terbaik, bukan sebaliknya demi mendapatkan keuntungan yang sebanyak banyaknya untuk laku menurunkan kualitas suatu produk. Produk kerupuk yang dihasilkan pelaku usaha kerupuk Desa Tlasih merupakan buatan tangan sendiri dan halal. Ada beberapa jenis kerupuk yang dihasilkan oleh pelaku usaha kerupuk, pertama ada kerupuk tahu, impala, manggar.

b. Harga

Tidak menggunakan unsur riba. Penetapan harga dalam perspektif syariah, tidaklah terlalu rumit, dasar penetapan harga bertumpu pada besaran nilai atau harga suatu produk yang tidak boleh ditetapkan dengan berlipat ganda besarnya, setelah dikurangi dengan biaya produksi.

Berkenaan dengan hal tersebut Allah SWT berfirman dalam surah Al-Imran 
ayat 130 yang berbunyi:

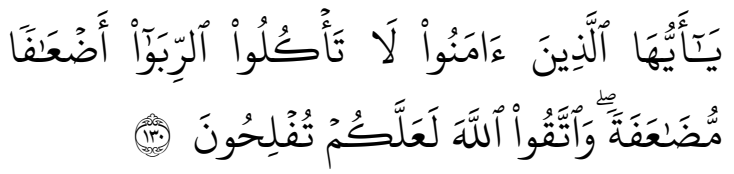

Artinya:"Hai orang-orang yang beriman, janganlah kamu memakan riba dengan berlipat ganda dan bertakwalah kamu kepada Allah supaya kamu mendapat keberuntungan”. (Q.S. Al Imran ayat 130)

Penetapan harga merupakan salah satu elemen penting bagi manajemen pabrik, dan terjangkau oleh daya beli masyarakat. Harga akan dipertimbangkan dari besarnya biaya yang di butuhkan seperti biaya bahan baku, harga pokok produksi, biaya promosi. Harga produk produk kerupuk yang dijual ini mulai dari $\mathrm{Rp}$. 50.000 sampai Rp. 60.000 (harga disesuaikan dengan jumlah pembelian).

c. Tempat

Dalam perspektif syariah, saluran pemasaran atau tempat lokasi pemasaran bisa dimana saja asalkan tempat tersebut bukan tempat yang dipersengketakan keberadaannya. Namun Islam lebih menekankan pada kedekatan perusahaan dengan pasar. Hal ini untuk menghindari adanya aksi pencegatan barang sebelum sampai ke pasar. Dalam sebuah Hadits yang artinya: "Ibnu Umar berkata: "Sesungguhnya Rasulullah melarang seseorang mencegat barang dagangan sebelum tiba di pasar." (HR. Muslim).

Saluran kegiatan distribusi yang terkait dengan berbagai aktivitas pabrik untuk mengupayakan agar produk dapat disalurkan ke konsumen. Sebagian besar produk dijual secara manual sehingga produk langsung ke tangan konsumen agar terhindar adanya penipuan. Namun letak pabrik di Jl. Raya Tlasih Tulangan Sidoarjo yang bukan merupakan akses jalan utama untuk konsumen langsung menjangkau tempat lokasi.

d. Promosi

Promosi dalam perspektif syariah merupakan suatu upaya penyampaian informasi yang benar terhadap produk barang atau jasa kepada konsumen atau pelanggan. Dalam sebuah hadits disebutkan: "Ibnu Umar berkata: Seorang laki-laki mengadu pada Nabi, "Aku telah tertipu dalam jual beli." Maka beliau bersabda, "Katakanlah kepada orang yang kamu ajak berjual beli, "Tidak bolehmenipu!" Sejak itu, jika ia bertransaksi jual beli, ia mengatakannya (HR. Bukhari).

\section{Etika dalam Pemasaran Syariah}

Untuk membangun bisnis yang sehat yang sesuai dengan kaidah Islam, kegiatan pemasaran harus berlandaskan nilai-nilai Islami yang dijiwai oleh semangat dalam beribadah kepada Allah SWT dan berusaha sebisa mungkin untuk kesejahteraan bersama. Adapun beberapa hal yang harus diperhatikan oleh pemasaran sebagai etika dalam pemasaran menurut Islam yaitu :

a. Memiliki akhlak yang baik, akhlak yang sesuai adalah seperti sifat Rasullah yaitu siddiq, amanah, tabligh dan fathanah. Memiliki kepribadian yang baik sehingga melakukan pemasaran tidak sematamata untuk kepentingan sendiri melainkan untuk menolong sesama.

b. Melayani pelanggan dengan sikap rendah hati, rendah hati dan sikap lemah lembut sangat dianjurkan dalam Islam dan Rasulullah SAW bahkan diperintahkan oleh Allah SWT untuk bersikap demikian.

c. Bersikap adil, keadilan merupakan transaksi jual beli atau kegiatan pemasran yang terjadi antara penjual dan pembeli dengan sikap tidak saling menzolimi.

d. Bersikap jujur dan terpercaya, kejujuran ini larangan terhadap segala bentuk tindakan penipuan dalam perkataan atau perbuatan.

e. Tidak melakukan suap (risywah).

Dari hasil penyajian penelitian 
diperoleh berdasarkan wawancara di Desa Tlasih Tulangan Sidoarjo pada tahun 2021. Berikut ini uraian analisis SWOT yang terdiri dari kekuatan, kelemahan, peluang dan ancaman dan menentukan faktor Internal Eksternal sebagai berikut:

\section{Tabel 1. Analisis Faktor Internal SWOT Kerupuk}

\begin{tabular}{|c|c|}
\hline $\begin{array}{c}\text { FaktorStrategi } \\
\text { Internal }\end{array}$ & Indikator \\
\hline Kekuatan & $\begin{array}{l}\text { 1. Harga produk telah disesuaikan dengandaya beli konsumen. } \\
\text { 2. Produk selalu berinovasi dan halal } \\
\text { 3. Kualitas produk yang ditawarkan terjamin produk jelas bagus dan } \\
\text { tidak mengandung bahan pengawet. } \\
\text { 4. Banyak variasi yang dijual sehingga konsumen mudah memilih } \\
\text { produk. }\end{array}$ \\
\hline Kelemahan & $\begin{array}{l}\text { 1. Promosi masih menggunakan bannerdan spanduk. } \\
\text { 2. Penjualan masih menggunakan metode } \\
\text { manual. } \\
\text { 3. Tempat pemasaran kurang luas } \\
\text { 4. Tempat pemasaran masih rawan polusi } \\
\text { 5. Kualitas produk tidak tahan lama } \\
\end{array}$ \\
\hline
\end{tabular}

Sumber: Data Olahan (2021)

Tabel 2. Analisis Faktor Eksternal SWOT Kerupuk

\begin{tabular}{cll}
\hline $\begin{array}{c}\text { Faktor Strategi } \\
\text { Eksternal }\end{array}$ & & \multicolumn{1}{c}{ Indikator } \\
\hline & 1. & Letaknya yang strategis \\
2. & Pemasaran bisa melalui secara online \\
& 3. & Produk bisa dikirim keluar Kota \\
& 4. & Melakukan kerjasama dengan pelanggan agar bisa dikenal lebih oleh \\
& & masyarakat \\
& 5. & Tempat pemasaran dekat dengan jalan raya dan ramai kendaraan \\
& 1. & Banyaknya usaha kerupuk yang sama \\
& 2. & Seiring dari tahun ke tahun bahan baku mengalami kenaikan harga \\
& 3. & Pengiriman keluar kota bisa membuat kualitas produk menurun \\
& 4. & Banyaknya penipuan karena letak pemasaran dekat dengan keramaian \\
& 5. & jalan raya \\
& & Beralihnya pelanggan pada pesaing yang sejenis \\
\hline
\end{tabular}

Sumber: Data Olahan (2021)

Tabel 3. Analisis Bauran Pemasaran Berdasarkan SWOT

\begin{tabular}{|c|c|c|c|c|}
\hline $\begin{array}{c}\text { SWOT } \\
\text { Bauran } \\
\text { Pemasaran }\end{array}$ & $\begin{array}{l}\text { Kekuatan } \\
\text { (Strenght) }\end{array}$ & $\begin{array}{l}\text { Kelemahan } \\
\text { (Weakness) }\end{array}$ & $\begin{array}{c}\text { Peluang } \\
\text { (Opportunity) }\end{array}$ & $\begin{array}{c}\text { Ancaman } \\
\text { (Threats) }\end{array}$ \\
\hline $\begin{array}{c}\text { Produk } \\
\text { (Product) }\end{array}$ & $\begin{array}{c}\text { Kualitas produk } \\
\text { yang ditawarkan } \\
\text { terjamin, produk } \\
\text { jelas bagus dan } \\
\text { tidak } \\
\text { mengandung } \\
\text { bahan pengawet. }\end{array}$ & $\begin{array}{l}\text { Penjualan masih } \\
\text { menggunakan } \\
\text { metode manual } \\
\text { dan Tempat } \\
\text { pemasaran masih } \\
\text { rawan polusi }\end{array}$ & $\begin{array}{c}\text { Melakukan } \\
\text { kerjasama dengan } \\
\text { pelanggan agar bisa } \\
\text { dikenal lebih oleh } \\
\text { masyarakat dan } \\
\text { Tempat pemasaran } \\
\text { dekat dengan jalan } \\
\text { raya dan ramai } \\
\text { kendaraan }\end{array}$ & $\begin{array}{c}\text { Beralihnya pelanggan } \\
\text { pada pesaing yang } \\
\text { sejenis }\end{array}$ \\
\hline
\end{tabular}


2021, Jurnal Tabarru' : Islamic Banking and Finance 4 (2) : 431 - 444

\begin{tabular}{|c|c|c|c|c|}
\hline $\begin{array}{l}\text { Harga } \\
\text { (Price) }\end{array}$ & $\begin{array}{c}\text { Harga terjangkau } \\
\text { dengan kualitas } \\
\text { bagus }\end{array}$ & $\begin{array}{l}\text { Harga bahan } \\
\text { pokok dari tahun } \\
\text { ke tahun } \\
\text { mengalami } \\
\text { kenaikan }\end{array}$ & $\begin{array}{c}\text { Konsumen yang } \\
\text { membeli produk } \\
\text { kerupuk dengan } \\
\text { jumlah banyak maka } \\
\text { akan di beri harga } \\
\text { khusus } \\
\end{array}$ & $\begin{array}{c}\text { Adanya para pesaing } \\
\text { yang menjual } \\
\text { produknya dengan } \\
\text { harga lebih murah }\end{array}$ \\
\hline $\begin{array}{c}\text { Promosi } \\
\text { (Promotion) }\end{array}$ & $\begin{array}{l}\text { Menggunakan } \\
\text { spanduk atau } \\
\text { baner di depan } \\
\text { toko }\end{array}$ & $\begin{array}{l}\text { Promosi masih } \\
\text { menggunakan } \\
\text { metode manual }\end{array}$ & $\begin{array}{c}\text { Melakukan } \\
\text { kerjasama dengan } \\
\text { pelanggan dalam } \\
\text { mempromosikan } \\
\text { produk sehingga } \\
\text { dapat menarik minat } \\
\text { konsumen }\end{array}$ & $\begin{array}{l}\text { Produsen lain juga } \\
\text { mempromosikan } \\
\text { produk dengan cara } \\
\text { menyebar brosur } \\
\text { kepada masyarakat } \\
\text { dan memasang baner }\end{array}$ \\
\hline $\begin{array}{l}\text { Tempat } \\
\text { (Place) }\end{array}$ & $\begin{array}{l}\text { Lokasi mudah di } \\
\text { jangkau dan } \\
\text { strategis }\end{array}$ & $\begin{array}{l}\text { Lokasi rawan } \\
\text { polusi }\end{array}$ & $\begin{array}{l}\text { Lokasi di dekat jalan } \\
\text { raya }\end{array}$ & $\begin{array}{c}\text { Adanya produsen yang } \\
\text { menjual produk sejenis } \\
\text { di sekitar lokasi }\end{array}$ \\
\hline
\end{tabular}

Sumber: Data Olahan (2021)

Dampak Penerapan Strategi Pemasaran Dalam Upaya Peningkatan Daya Saing UMKM Desa Tlasih Tulangan Sidoarjo

Indikator yang digunakan untuk mengetahui dampak strategi pemasaran dalam upaya meningkatkan daya saing Usaha Mikro Kecil dan Menengah (UMKM) Desa Tlasih menggunakan teori ilmiah yang menjadi rujukan indikator meningkatkan daya saing dengan menggunakan strategi pemasaran. Perkembangan perekonomian di Indonesia sangat berpengaruh dari besar atau kecilnya suatu usaha meskipun hanya mempengaruhi sebagian kecil, akan tetapi Usaha Mikro Kecil dan Menengah (UMKM) dapat memulihkan suatu kondisi krisis ekonomi yang menimpa suatu wilayah.

Saat ini Usaha Mikro Kecil dan Menengah (UMKM) sudah merambah di berbagai wilayah Indonesia dengan berbagai macam aneka ragam produk baik di bidang dagang maupun jasa. Keberadaan Usaha Mikro Kecil dan Menengah (UMKM) juga tidak terlepas dari strategi pemasaran yang mereka terapkan dalam memasarkan produk.

Setiap pengusaha tentu tidak ingin mengalami dampak berupa kerugian, namun kerugian itu tentu akan terjadi apabila setiap pelaku usaha mengabaikan usaha yang seharusnya ditekuni tersebut. Adanya penerapan strategi yang tepat akan menghasilkan dampak yang luar biasa, namun apabila strategi yang diterapkan belum mampu menarik minat konsumen tentu akan memberikan dampak kerugian berupa tenaga, uang maupun waktu. Di dalam penerapan strategi pemasaran mempunyai Dampak positif dan negatif. Berikut ini merupakan dampak positif yang didapat dari penerapan strategi pemasaran di Desa Tlasih.

Gambar 3. Dampak Positif Dari Penerapan Strategi Pemasaran di Desa Tlasih 2021
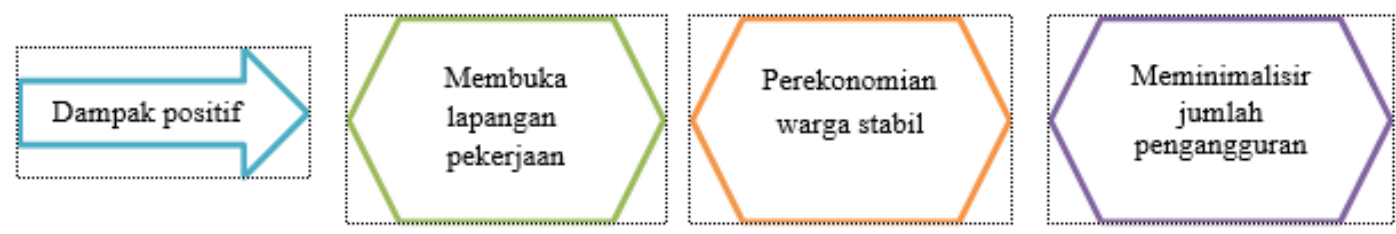

Sumber: Data Olahan (2021)

Dari gambar di atas, terdapat dampak positif yang ditimbulkan bagi warga Desa Tlasih yaitu: Pertama, membuka lapangan pekerjaan bagi warga disekitar lingkungan
Desa Tlasih. Warga desa berpendapat bahwa adanya Usaha Mikro Kecil dan Menengah (UMKM) membuat warga desa sangat terbantu dengan dibukanya lapangan 
pekerjaan, mereka juga dapat menstabilkan perekonomian keluarga (keuangan menjadi stabil) sehingga meminimalisir jumlah pengangguran. Dalam kaitannya strategi pemasaran yang dilakukan pelaku Usaha Mikro Kecil dan Menengah (UMKM) sampai saat ini masih aman terkondisikan meskipun tidak mengikuti perkembangan modern dengan sisten pemasaran melalui online.

Kedua, dampak positif di Desa Tlasih sendiri yaitu mereka menggunakan cara manual untuk memperkenalkan produk mereka secara langsung kepada masyarakat. tinggi dalam memperkenalkan produk secara manual akan tetapi hal tersebut merupakan langkah termudah dalam memasarkan produk terutama di Desa Tlasih dan bagi pelaku Usaha Mikro Kecil dan Menengah (UMKM), pelaku Usaha Mikro Kecil dan Menengah (UMKM) akan mendapat keuntungan karena selain usahanya dapat berjalan dengan baik dan juga mendapat dukungan dari warga sekitar yang dapat memberikan dampak positif karena usaha yang didirikan pelaku Usaha Mikro Kecil dan Menengah (UMKM) akan lebih mudah mengoperasionalkannya.

Memang membutuhkan kesabaran yang

Gambar 4. Pendapatan Tahun 2019-2020

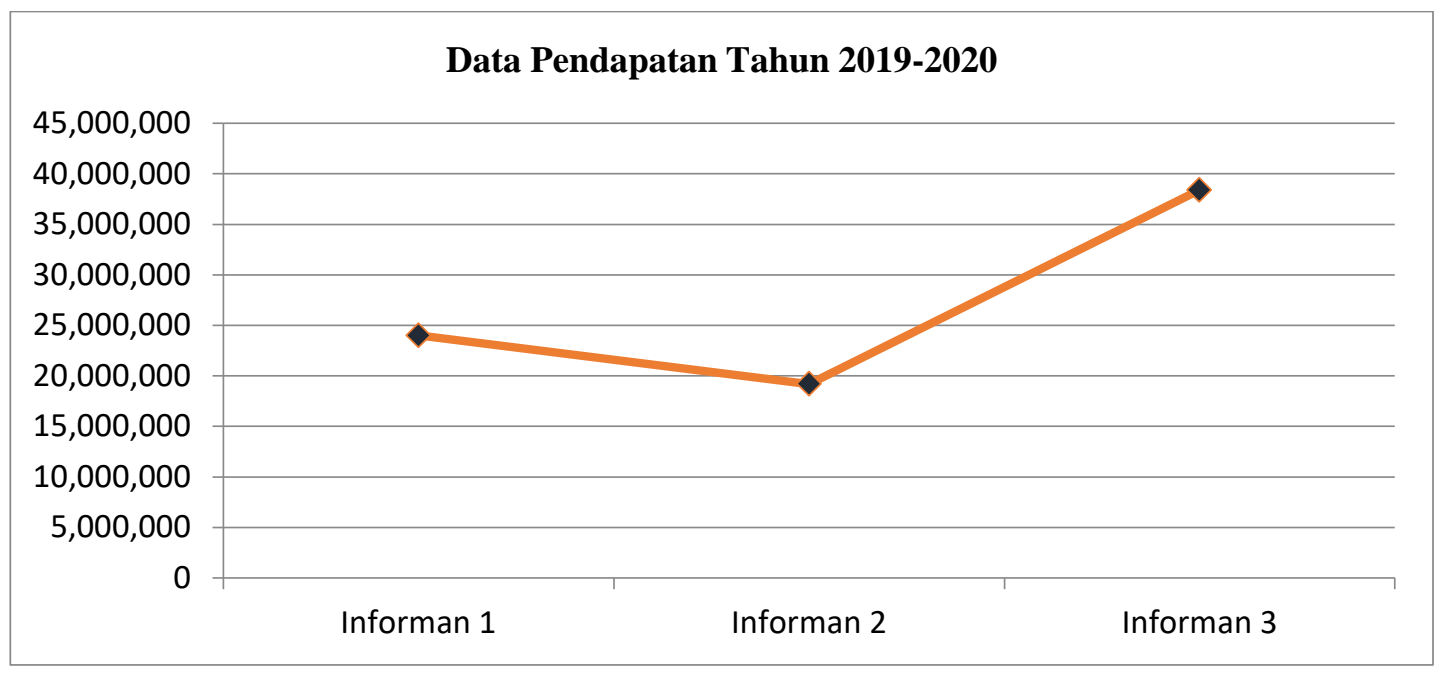

Sumber: Data Olahan (2021)

Dari diagram di atas dapat dilihat bahwa perolehan pendapatan dari informan pertama dan informan ketiga mengalami penurunan dan kenaikan hal tersebut di karenakan banyak nya pesaing sejenis di lingkungan sekitar sehingga mempengaruhi pendapatan (omset) yang diperoleh oleh pabrik.

Sedangkan dampak negatif dari perilaku strategi pemasaran yang dilakukan pelaku Usaha Mikro Kecil dan Menengah (UMKM) di Desa Tlasih yaitu: pertama, produk tidak tahan lama karena proses pembuatannya tidak menggunakan bahan pengawet. Penggunaan bahan pengawet sesuai takaran tidak akan mengubah produk baik dari warna, rasa maupun tampilan, tetapi pada dasarnya pengawet makanan dibuat untuk mengawetkan makanan atau minuman agar ketika didistribusikan ke tempat yang jauh tidak akan cepat busuk dan dapat dikonsumsi dalam jangka panjang.

Kedua, strategi pemasaran yang dilakukan oleh pelaku Usaha Mikro Kecil dan Menengah (UMKM) tersebut bisa menembus pasar nasional pemasaran yang dapat menembus skala nasional dengan cepat yaitu dengan memasarkan secara online, namun karena terbatasnya tenaga dan waktu membuat pelaku Usaha Mikro Kecil dan Menengah (UMKM) tidak menjual online dagangannya dan setiap pengusaha memiliki pelanggan masingmasing di berbagai kota. Pemasaran yang dilakukan pun masih menggunakan cara manual. Jika pelaku Usaha Mikro Kecil dan Menengah (UMKM) hanya mengandalkan 
dagangan mereka secara offline terus menerus tidak menutup kemungkinan mereka akan tertinggal oleh zaman dan daya saing penjualan mereka dapat turun.

\section{KESIMPULAN}

Berdasarkan hasil dari wawancara strategi pemasaran untuk meningkatkan daya saing Usaha Mikro Kecil dan Menengah (UMKM) kerupuk Desa Tlasih diketahui : Pertama, penerapan strategi pemasaran yang dilakukan dalam upaya peningkatan daya saing penjualan di Desa Tlasih menggunakan bauran pemasaran 4P yang terdiri dari product, place, price, promotion dan pemasarannya masih manual. Oleh karena itu juga dibutuhkan adanya strategi pemasaran dengan menggunakan sistem online karena dengan adanya sistem online para pelaku usaha tidak kewalahan dalam pemasarannya dan bisa menciptakan inovasi baru dalam produknya. Kedua, dalam penerapan strategi pemasaran untuk meningkatakan daya saing penjualan terdapat dua dampak yaitu positif dan negatif, dampak positif para pelaku usaha bisa menciptakan lapangan pekerjaan bagi warga desa itu sendiri, dan dampak negatifnya produknya tidak tahan lama karena tidak menggunakan bahan pengawet dan strategi pemasaran yang dilakukan oleh pelaku usaha masih menggunakan pemasaran secara manual.

\section{DAFTAR PUSTAKA}

Ariwibowo, Muhamad Eko. 2019. Strategi Pemasaran Lembaga Pendidikan Tinggi Swasta. SCIENTIFIC JOURNAL OF REFLECTION: Economic, Accounting, Management and Business, 2(2), p. 181-190.

Atmoko, Temoteus Prasetyo Hadi. 2018. Strategi Pemasaran Untuk Meningkatkan Volume Penjualan Di Cavinton Hotel Yogyakarta. Journal of Indonesian Tourism, Hospitality and Recreation, 1(2), p. 83-96.

Kusumastuti, Adhi dan Khoiron, Ahmad
Mustamil. 2019. Metode Penelitian Kualitatif. Lembaga Pendidikan Sukarno Pressindo. Semarang.

Latifah, Fitri Nur., Maika, M. Ruslianoor., \& Ariyanti, Novia. 2019. PKM Geo UMKM Desa Kenongo. Jurnal Pemberdayaan : Publikasi Hasil Pengabdian kepada Masyarakat, 3(3), p. 259-266.

Mohamad, Rifki., \& Niode, Idris Yanto. 2020. Analisis Strategi Daya Saing (Competitive Advantage) Kopia Karanji Gorontalo. Oikos-Nomos: Jurnal Kajian Ekonomi dan Bisnis, 13(1), p. 1-14.

Ningsih, Desy Dwi Sulastriya ., \& Maika, M. Ruslianor. 2020. Strategi Bauran Pemasaran 4P Dalam Menentukan Sumber Modal Usaha Syariah Pedagang Pasar Di Sidoarjo. Jurnal Ilmiah Ekonomi Islam (JIEI), 6(03), p. 693702.

Nugrahani, Farida. 2014. Metode Penelitian Kualitatif Dalam Penelitian Pendidikan Bahasa. Cakra Book. Solo.

Nurcholifah, Ita. 2014. Strategi Marketing Mix Dalam Perspektif Syariah. Jurnal Khatulistiwa-Journal of Islamic Studies, 4(1), p. 73-86.

Oktafia, Renny. 2017. Percepatan Pertumbuhan Usaha Mikro, Kecil Dan Menengah (UMKM) Melalui Perkuatan Lembaga Keuangan Mikro Syariah (LKMS) Di Jawa Timur. Jurnal Ekonomi Islam, 3(1), p. 85-92.

Raco, Jozef. 2018. Metode Penelitian Kualitatif: Jenis, Karakteristik Dan Keunggulannya. PT. Grasindo. Jakarta

Sani, Ageng Asmara., Wicaksana, Ragil Satria., \& Ilmiah, Dunyati. 2019. Implikasi Adiba MSME Sebagai Instrumen Channeling Masyarakat UMKM Dalam Menggunakan Layanan Lembaga Keuangan Syariah. Jurnal Tabarru': Islamic Banking and Finance, 2(2), p. 38-49.

Shidiq, Umar., \& Choiri, Miftachul. 2019. 
2021, Jurnal Tabarru' : Islamic Banking and Finance 4 (2) : 431 - 444

Metode Penelitian Kualitatif Di Bidang

Pendidikan. CV. Nata Karya. Ponorogo.

Sudiarta, I Putu Lanang Eka., \& Kirya, I

Ketut \& Cipta, I. Wayan. 2014. Analisis

Faktor-Faktor Yang Mempengaruhi

Kinerja. Jurusan Manajemen Indonesia, 2(1).

Sukatmadiredja, Noneng. R., \& Rosita, Windy Mella. 2019. Strategi Pemasaran Melalui Analisis SWOT Pada

Perusahaan Kopi Lokal. Jurnal

Ecopreneur.12 Fakultas Ekonomi Dan

Bisnis, 2(2), p. 12-25. 